\title{
Differentiation of virescence MLOs using western aster yellows mycoplasma-like organism chromosomal DNA probes and restriction fragment length polymorphism analysis
}

\author{
Cheryl R. Kuske, ${ }^{1} \dagger$ Bruce C. Kirkpatrick $^{1 *}$ and Erich Seemüller ${ }^{2}$ \\ ${ }^{1}$ Department of Plant Pathology, University of California, Davis, CA 95616, USA \\ ${ }^{2}$ Biologische Bundesanstalt für Land- und Forstwirtschaft, Institut für Pflanzenschutz im Obstbau, \\ D-6915 Dossenheim, Germany
}

(Received 18 June 1990; revised 21 September 1990; accepted 28 September 1990)

\begin{abstract}
Two chromosomal fragments of the severe strain (SAY) of the western aster yellows mycoplasma-like organism (MLO) were cloned in Escherichia coli. These fragments were used to probe Southern blots of DNA extracted from plants infected with geographically and pathologically diverse MLOs. The two SAY probes hybridized with some, but not all, of the virescence-inducing MLOs examined, indicating that some of these MLOs are genetically related. Comparisons of restriction fragment length polymorphisms of MLO DNA established additional relationships within this group. The SAY-MLO probes did not hybridize with decline-inducing MLOs, plant pathogenic spiroplasmas, or healthy plants.
\end{abstract}

\section{Introduction}

Mycoplasma-like organisms (MLOs) have been implicated as the causal agents of disease in several hundred plant species (McCoy et al., 1989). To date, MLOs have not been cultured in vitro. For this reason, diagnosis of MLO-induced disease and classification of MLOs have historically relied upon electron microscopic observation of MLOs in the plant phloem, symptoms expressed by infected plants, and the specificity of transmission by insect vectors. Plant-pathogenic MLOs can be broadly classified by the symptoms they produce in plants (reviewed by Kirkpatrick, 1989, 1991). Some MLOs produce symptoms of virescence (greening of floral tissues) and phyllody (leaflike petals and sepals) in their herbaceous hosts (virescence MLOs). Others do not produce virescence and phyllody but rather produce a general decline of infected plants (decline MLOs). However, members of both groups can produce similar symptoms, such as chlorosis, stunting, and shoot proliferation. Thus, classification of MLOs based solely on disease symptoms cannot precisely differentiate all of the

† Present address: Genetics Group, Life Sciences Division, Mail Stop M886, Los Alamos National Laboratory, Los Alamos, NM 87545, USA.

Abbreviations: MLO, mycoplasma-like organism; RFLP, restriction fragment length polymorphism.
MLOs. In addition, because plant host range and vector transmission characteristics are time consuming and often difficult to obtain, these characteristics have not been determined for most of the MLOs. The reliance upon biological and pathological characteristics to classify MLOs has resulted in confusion in naming MLOs and distinguishing between different MLO isolates.

The need for more reliable and specific traits to classify MLOs has resulted in the development of MLOspecific serological and DNA hybridization assays. The production of polyclonal and monoclonal antibodies against MLO immunogens has allowed sensitive detection of these pathogens in infected hosts using enzyme-linked immunosorbent assay (ELISA) and immunosorbent electron microscopy (ISEM) (reviewed by Kirkpatrick, 1991). Fragments of MLO chromosomes have been cloned from MLO-infected insects (Kirkpatrick et al., 1987; Davis et al., 1988) and plants (Lee \& Davis, 1988; Sears et al., 1989; Kollar et al., 1990; Lee et al., 1990). Cloned MLO DNAs have been used as probes in DNA hybridization assays to detect these pathogens in plant and insect hosts and to evaluate the genetic relatedness of MLOs. The ability to differentiate MLOs on the basis of their serological or genetic characteristics, rather than on phenotypic characters expressed by their infected hosts, can provide a more reliable and detailed basis for MLO classification. 
The objectives of this study were to clone chromosomal fragments of the western aster yellows MLO (AY$M L O)$, and use them to identify genetic relationships between this MLO and other geographically and pathologically distinct MLOs. An abstract of this work has been published (Kuske \& Kirkpatrick, 1989).

\section{Methods}

Mycoplasma-like organisms. Celery (Apium graveolens L.) and China aster (Callistephus chinensis Nees) plants, and Macrosteles severini Hamilton leafhoppers infected with the severe (SAY), dwarf (DAY) or Tulelake (TLAY) strains of western AY-MLO (Freitag, 1964) were provided by A. H. Purcell, Department of Entomology, University of California, Berkeley. Periwinkle (Catharanthus roseus L.) plants infected with SAY, DAY, TLAY, two California field isolates of AYMLO (AY-HR and AY-DAV), X-disease MLO (X), elm yellows MLO (EPN, provided by W. A. Sinclair via R. E. Davis, USDA-ARS, Beltsville, Maryland), or an incompletely characterized MLO isolated from pear in California [PD(X)]; Raju et al., 1983) were maintained in the greenhouse by grafting infected shoots onto healthy plants. Periwinkle infected with the beet-leafhopper-transmitted virescence agent (BLTVA; Golino et al., 1987) was provided by D. A. Golino, USDA-ARS, Department of Plant Pathology, University of California, Davis. A Florida isolate of maize bushy stunt MLO(MBS; Davis $e t$ al., 1988) and a Wisconsin isolate of eastern AY-MLO (WAY) were provided by $M$. Davis, University of Florida, Homewood. A New Jersey isolate of eastern AY-MLO (EAY; Jiang \& Chen, 1987) in lettuce was provided by T. A. Chen, Department of Plant Pathology, Rutgers University, NJ. MLO-infected Oenothera (OAY; Sears et al., 1989) tissue was provided by B. Sears, Department of Plant Pathology and Botany, Michigan State University. Periwinkle infected with a Canadian isolate AY-27 of AY-MLO (CAY, AY-2), clover proliferation (CP), and potato witches' broom (PWB) MLOs were provided by C. Hiruki, Department of Plant Science, University of Alberta, Canada. MLOs causing phyllody in sesame (SESP), and white leaf disease of Bermuda grass (BG), and sugarcane (WL), were collected in their native host plants near Khon Kaen, Thailand.

Preparation of total DNA extracted from periwinkle (Kollar $e t$ al., $1990)$ infected with apple proliferation (AT), rape virescence (RV), stolbur (ST), safflower phyllody (SP), Diplotaxis virescence (DIV), Catharanthus virescence (CV), and European aster yellows (AV) MLOs were purified by DEAE-cellulose chromatography (Elutip-d columns, Schleicher and Schuell) and precipitated twice with ammonium acetate and ethanol. DNA from Veitchia palm infected with coconut lethal yellows MLO (LY) was provided by N. Harrison, IFAS/REC, Ft Lauderdale, FL. DNAs from Spiroplasma citri (Maroc isolate) and $S$. kunkelii (California isolate 245) were isolated as described previously (Kuske \& Kirkpatrick, 1990).

MLO enrichment and DNA extraction. Symptomatic MLO-infected and healthy shoot tissues were ground in cold PS buffer (Davis et al., 1988), without fructose, using a mortar and pestle, and filtered through Miracloth (Behring Diagnostics). The filtrate was centrifuged for $7 \mathrm{~min}$ at $2300 \mathrm{~g}$ at $4{ }^{\circ} \mathrm{C}$, the pellet was discarded and the resulting supernatant was then centrifuged at $17500 \mathrm{~g}$ for $30 \mathrm{~min}$ to pellet the MLOs and some host constituents (primarily mitochondria). DNA was extracted from this MLO-enriched fraction, precipitated, and stored as described by Kuske \& Kirkpatrick (1990). DNA extracted from healthy celery fed on by healthy leafhoppers, or other healthy plant species, served as experimental controls.

Cloning and identification of MLO-specific DNA fragments. Unless otherwise indicated, the laboratory reagents, general cloning and hybridization techniques used in this study are described in Maniatis et al. (1982) and Ausubel et al. (1987). DNA from celery infected with the severe strain (SAY) of western AY-MLO (Freitag, 1964) was purified in caesium chloride/ethidium bromide $(\mathrm{CsCl} / \mathrm{EtBr})$ density gradients and then digested with EcoRI. Digested fragments were ligated with EcoRI-digested, dephosphorylated pUC18 (Yanisch-Perron et al., 1985). Ligated plasmids were used to transform competent Escherichia coli, strain JM109. Transformants containing recombinant plasmids were identified by plating on Luria broth agar containing ampicillin, $\mathrm{X}$-Gal and IPTG. White, ampicillin-resistant colonies were transferred to duplicate nitrocellulose membranes overlaying media containing ampicillin, and grown at $37^{\circ} \mathrm{C}$. Cells on the membranes were lysed and DNA was bound to the membranes using standard protocols.

Transformants were screened for MLO-specific insert DNA by a differential hybridization assay, which selected for cloned, MLOspecific DNA fragments that did not have homology to either plant or leafhopper host DNA (Kirkpatrick et al., 1987). DNAs from MLOinfected celery and infected Macrosteles severini leafhoppers, and from both healthy hosts, were labelled with $\left.{ }^{32} \mathrm{P}\right] \mathrm{dATP}$ using random oligoprimers (Multiprime Kit, Amersham) and used as hybridization probes. Prehybridizations and hybridizations were performed at $42{ }^{\circ} \mathrm{C}$ in solutions containing $50 \%$ (v/v) formamide (Kirkpatrick et al., 1987). Blots were washed ( 30 min per wash) at moderate stringency: twice in $2 \times \mathrm{SSC}, 0.1 \% \mathrm{SDS}$ at $37^{\circ} \mathrm{C}$; once in $0.2 \times \mathrm{SSC}, 0.1 \% \mathrm{SDS}$ at $37 \%$; and once in $0.2 \times \mathrm{SSC}, 0.1 \% \mathrm{SDS}$ at $55^{\circ} \mathrm{C}$. At this stringency, hybridization between MLO sequences was readily detected, but there was no hybridization of MLO DNAs with DNA from cloning vectors or healthy plants.

Plasmid DNA was prepared by the alkaline lysis method from transformant colonies that hybridized with MLO-enriched DNA but not with healthy celery or leafhopper DNA. Recombinant plasmid DNA was denatured and applied to nitrocellulose membranes using a dot-blot manifold. Replicate dot-blots were hybridized with the four probes described above.

EcoRI-digested DNA from healthy, SAY- and DAY-MLO-infected celery and undigested DNA from SAY-MLO-infected celery were electrophoresed in $1 \%(\mathrm{w} / \mathrm{v})$ agarose gels using $1 \times$ Tris/borate buffer $(1 \times \mathrm{TBE})$, and transferred to nylon membranes. Replicate Southern blots were hybridized with ${ }^{32} \mathrm{P}$-labelled plasmid DNA from each of the recombinant plasmids that were previously identified as MLO-specific to verify the specificity of the cloned fragments and to determine whether the cloned fragments were from SAY-MLO chromosomal or extrachromosomal DNA. Two recombinant plasmids, containing 1.9 and $4.1 \mathrm{~kb}$ inserts, hybridized only with chromosomal DNA from SAY-infected hosts. The recombinant plasmids containing these fragments were designated $\mathrm{pAYC} 3$ and pAYC4, respectively.

Preparation of SAY-MLO chromosomal probes. Plasmid DNAs of pAYC3 and pAYC4 were purified on $\mathrm{CsCl} / \mathrm{EtBr}$ gradients. Plasmid DNA was digested with $E c o$ RI and electrophoresed in $1 \%$ agarose gels (SeaKem GTG, FMC Bioproducts) using $1 \times$ Tris/acetate buffer. Cloned fragments of SAY-MLO DNA were electroeluted from excised gel pieces using an Elutrap chamber (Schleicher and Schuell). Gelpurified insert DNAs from pAYC3 and pAYC4 were labelled with [ $\left.{ }^{32} \mathrm{P}\right] \mathrm{dATP}$ and used to probe Southern blots of DNA from the MLOinfected and healthy plants described above.

Southern blot hybridizations. Sample DNAs were treated with RNAase A, extracted with phenol and chloroform, ethanol-precipitated, and digested with EcoRI. Approximately 0.8 to $1.0 \mu \mathrm{g}$ of digested DNA was electrophoresed in $1 \%$ agarose gels using $1 \times$ TBE, transferred onto nylon membranes, and probed with the ${ }^{32} \mathrm{P}$-labelled SAY chromosomal fragments from either pAYC 3 or pAYC4. Posthybridization washes were as previously described. Hybridized blots were exposed to $\mathrm{X}$-ray film at $-70^{\circ} \mathrm{C}$, using enhancer screens (Lighting Plus). 


\section{Results and Discussion}

\section{Cloning MLO-specific chromosomal fragments}

Approximately 1200 transformants were screened by differential hybridization. Southern blot hybridization verified that two of the recombinant plasmids contained MLO-specific fragments of the SAY chromosome. These were designated pAYC3 and pAYC4, and they contained cloned fragments that were 1.9 and $4.1 \mathrm{~kb}$ in size, respectively (Fig. $1 a, b$ ). Hybridization analysis showed that the two cloned fragments did not cross-hybridize at moderate stringency. No hybridization occurred between the cloned MLO fragments and DNA from healthy celery, lettuce, maize, periwinkle, sesame, Veitchia palm, or M. severini leafhoppers (Figs 1, 2, 3, and data not shown).

\section{Hybridization between $S A Y-M L O$ probes and other virescence MLOS}

In Southern blot analyses, the two SAY chromosomal probes hybridized with DNA from some but not all of the virescence MLOs (Table 1, Fig. 2). MLOs hybridizing with the SAY probes comprise a geographically diverse group that cause virescence and phyllody in a wide variety of plant hosts. Despite the common features of virescence and phyllody, symptoms produced by the members of this group can vary considerably and are often quite distinct from one another. This group of genetically related (SAY-related) virescence MLOs include MLOs from the United States (DAY, TLAY, EAY, WAY, OAY), Europe (AV, DIV, RV) and the Mediterranean region (ST, SP). The CV virescence isolate from Peru hybridized weakly with the pAYC3 insert but not with the pAYC4 insert. It is possible that the concentration of MLO DNAs in this preparation may have been too low to detect by this hybridization assay. However, it is also possible that this MLO isolate has homology with only one of the SAY-MLO fragments.

The DNAs used in this study were from MLOenriched fractions derived from infected plants. It is not possible to precisely determine the proportion of MLO DNA that is present in each of these preparations. Therefore, it is possible that MLO DNA concentrations in some of the samples were below the detectable limits of this assay. However, SAY and DAY were routinely detected, using pAYC4 as probe, in as little as $0.5 \mathrm{ng}$ of DNA prepared by these techniques (Kuske, 1989). Because 0.8 to $1.0 \mu \mathrm{g}$ of DNA was used in these Southern blot assays, it is likely that detectable quantities of MLO DNA were present. In addition, low-copy genes, such as the MLO 16S ribosomal RNA gene(s), were readily detected in similar DNA preparations from all of the

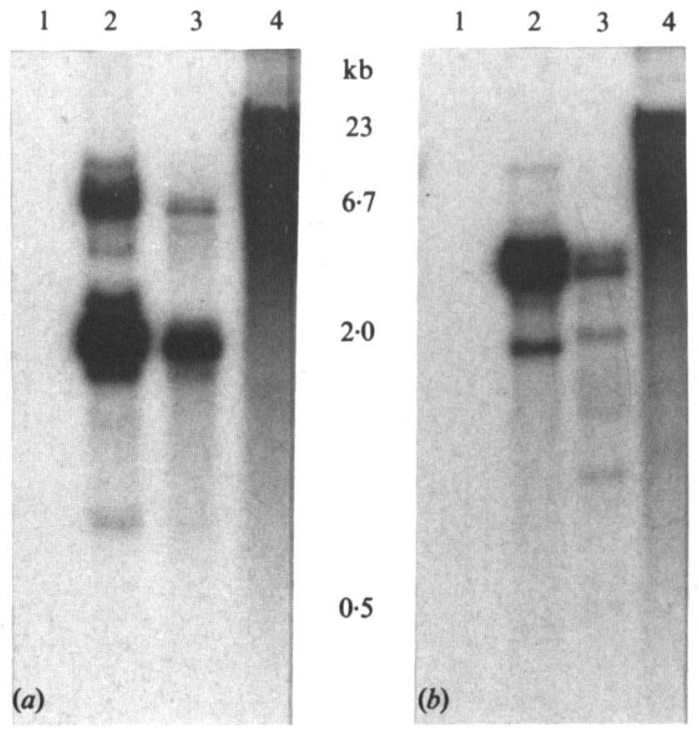

Fig. 1. Southern blot hybridization of EcoRI-digested DNA extracted from healthy celery (lane 1), SAY-MLO-infected celery (lane 2), DAYMLO-infected celery (lane 3), and undigested DNA from SAY-MLOinfected celery (lane 4). Southern blots were probed with ${ }^{32} \mathrm{P}$-labelled cloned inserts from $(a)$ pAYC3 or $(b)$ pAYC4.

California MLO isolates that are listed in Table 1 (B. C. Kirkpatrick, unpublished). Problems of detecting low concentrations of MLO DNA can be overcome by amplifying specific MLO sequences using the polymerase chain reaction (Schaff et al., 1990). Following amplification, these sequences could be digested with restriction endonucleases to yield MLO-specific RFLPs.

\section{Genetic differentiation of SAY-related virescence MLOS from decline-type MLOs and plant-pathogenic spiroplasmas}

The SAY chromosomal probes did not hybridize with any of the decline MLOs examined (Table 1, Fig. 3), indicating that the decline MLOs are not closely related to the SAY-related virescence MLOs. Lee \& Davis (1988) and Lee et al. (1990) also described groups of genetically related virescence MLOs based on dot-blot hybridization assays using cloned DNA fragments from an eastern AY-MLO isolate as probes. Their groupings depended on the specific clone used as a hybridization probe, type of hybridization probe (double-stranded DNA or single-stranded RNA), and the stringency of post-hybridization washes. Generally, the results they obtained using high-stringency conditions were similar to those presented here, i.e. a cluster of virescence MLOs could be distinguished from the decline MLOs. Dot-blot hybridizations using cloned chromosomal DNAs from the western X-MLO (a decline MLO) also support the 


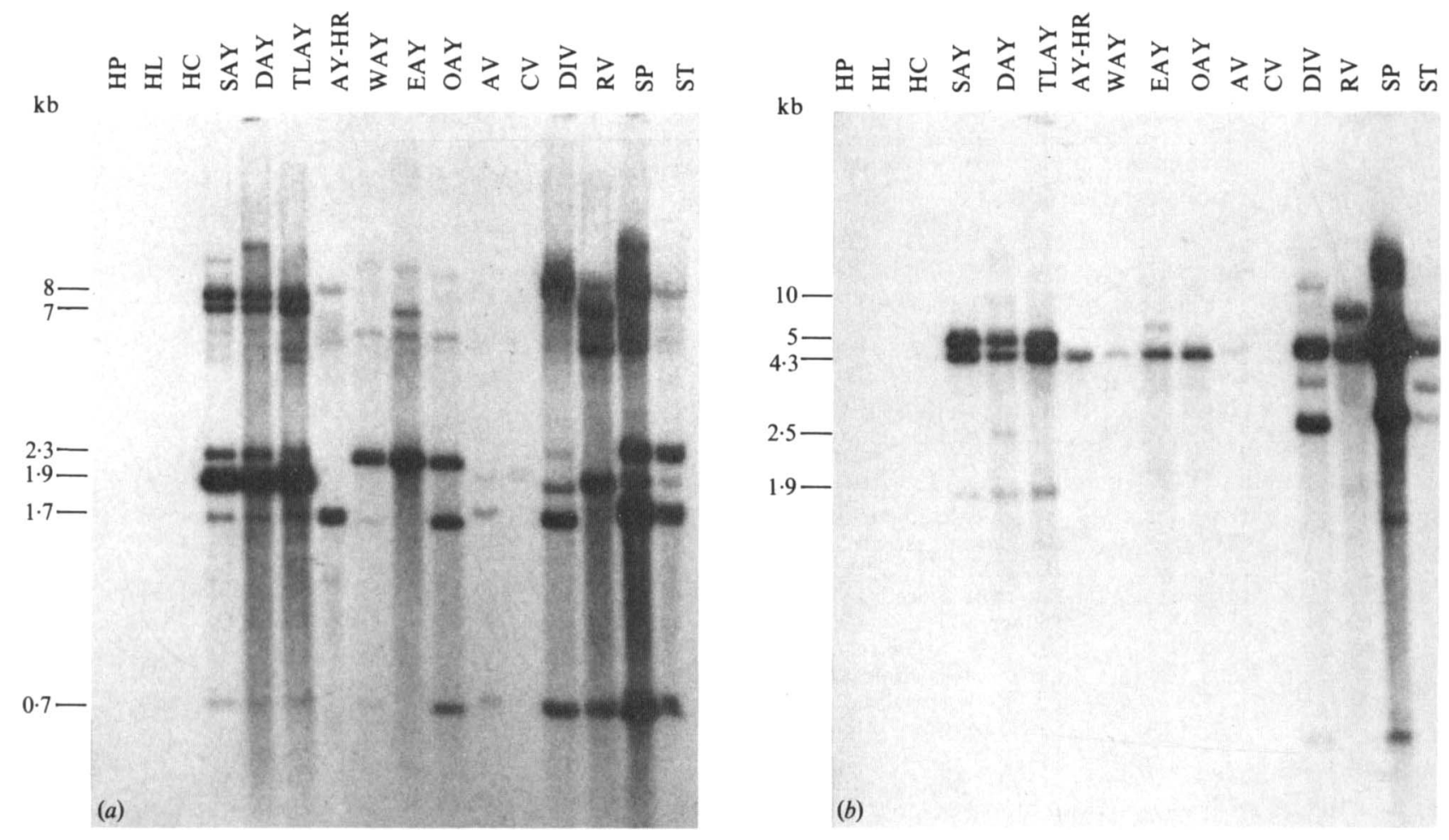

Fig. 2. Southern blot hybridization of EcoRI-digested DNA from MLO-infected plants exhibiting symptoms of virescence and/ or phyllody. See Table 1 for identity of sample codes. Blot $(a)$ was probed with a $1.9 \mathrm{~kb}$ SAY-MLO chromosomal DNA fragment from pAYC3, and blot (b) with a $4.1 \mathrm{~kb}$ SAY-MLO chromosomal DNA fragment from pAYC4, as described in the text. Controls on these blots are healthy periwinkle (HP), lettuce (HL), and celery (HC).

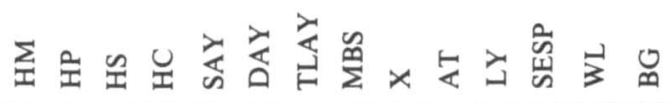

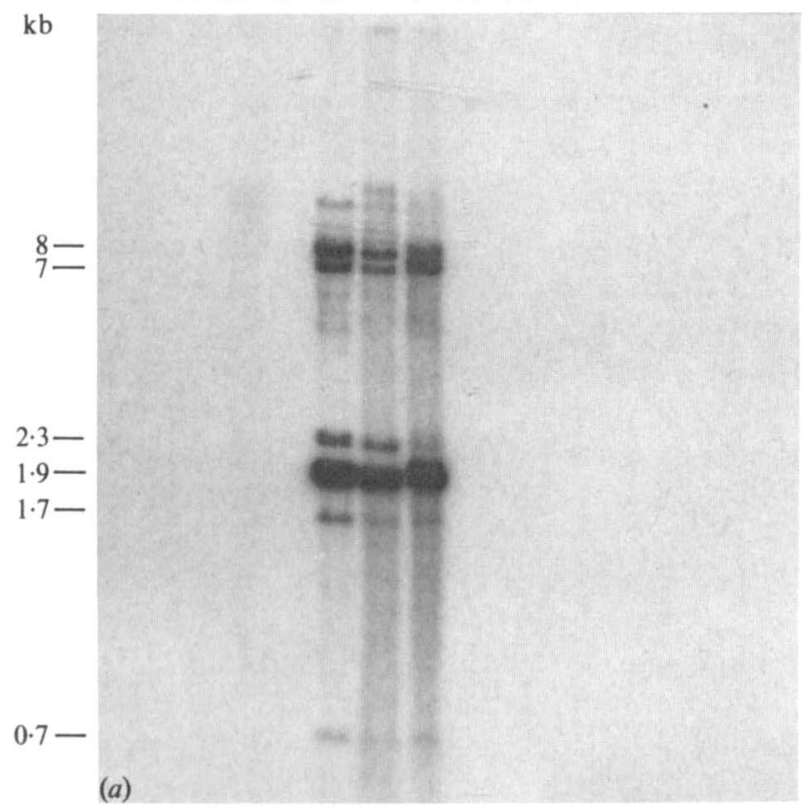

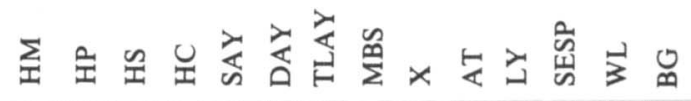

$\mathrm{kb}$

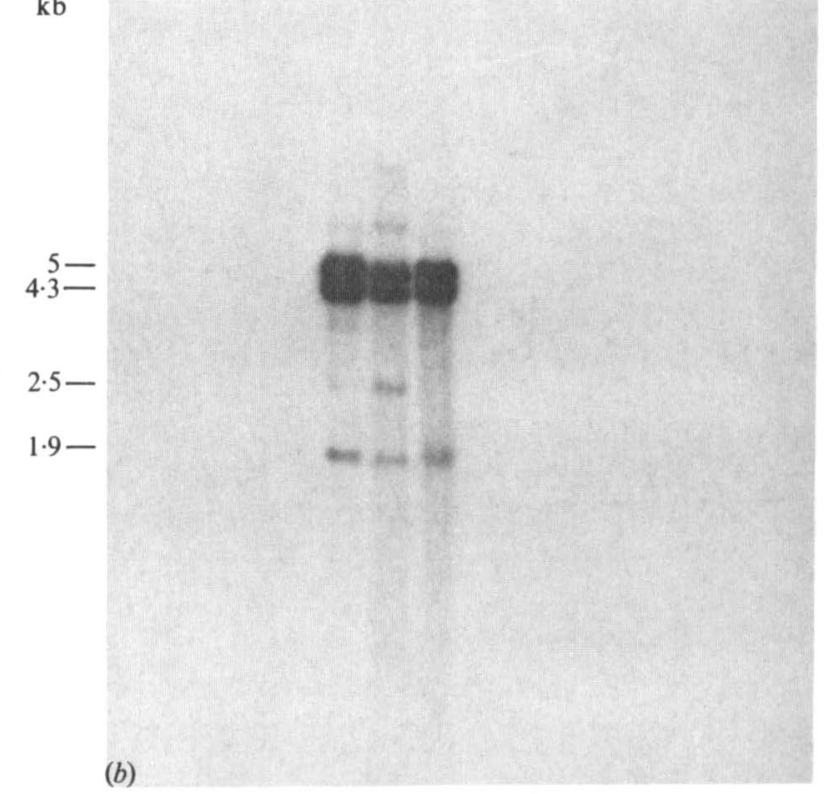

Fig. 3. Southern blot hybridization of EcoRI-digested DNA from MLO-infected plants. See Table 1 for identity of sample codes. Blot (a) was probed with a $1.9 \mathrm{~kb} \mathrm{SAY-MLO} \mathrm{chromosomal} \mathrm{DNA} \mathrm{fragment} \mathrm{from} \mathrm{pAYC3,} \mathrm{and} \mathrm{blot}(b)$ with a $4.1 \mathrm{~kb}$ SAY-MLO chromosomal DNA fragment from pAYC4. Controls on these blots are healthy maize (HM), periwinkle (HP), sugarcane (HS), and celery (HC). 
Table 1. Results of DNA hybridizations between ${ }^{32} P$-labelled $S A Y-$ $M L O$ chromosomal DNA fragments and DNAs from other geographically and pathologically diverse $M L O S$

\begin{tabular}{|c|c|c|c|c|}
\hline Code & MLO & Source & $\begin{array}{c}\text { Hybridization } \\
\text { with SAY } \\
\text { probes }\end{array}$ & $\begin{array}{c}\text { Figure } \\
\text { no. }\end{array}$ \\
\hline \multicolumn{5}{|c|}{ Virescence MLOs } \\
\hline SAY & Severe Western AY-MLO & California & + & $1,2,3$ \\
\hline DAY & Dwarf Western AY-MLO & California & + & $1,2,3$ \\
\hline TLAY & Tulelake Western AY-MLO & California & + & 2,3 \\
\hline AY-HR & Hanford AY-MLO & California & + & 2 \\
\hline AY-DAV & Davis AY-MLO & California & + & NS \\
\hline WAY & Eastern AY-MLO & Wisconsin & + & 2 \\
\hline EAY & Eastern AY-MLO & New Jersey & + & 2 \\
\hline AV & European AY-MLO & Germany & + & 2 \\
\hline CAY & Canadian AY-MLO & Alberta & - & NS \\
\hline OAY & Oenothera virescence & Michigan & + & 2 \\
\hline DIV & Diplotaxis virescence & Spain & + & 2 \\
\hline RV & Rape virescence & France & + & 2 \\
\hline ST & Stolbur & Yugoslavia & + & 2 \\
\hline SP & Safflower phyllody & Israel & + & 2 \\
\hline $\mathrm{CV}$ & Catharanthus virescence & Peru & $+1-^{*}$ & 2 \\
\hline BLTVA & Beet LH trans virescence & California & - & NS \\
\hline SESP & Sesame phyllody & Thailand & - & 3 \\
\hline $\mathrm{CP}$ & Clover proliferation & Alberta & - & NS \\
\hline PWB & Potato witches' broom & Alberta & - & NS \\
\hline \multicolumn{5}{|c|}{ Decline and other MLOs } \\
\hline $\mathrm{X}$ & X-disease & California & - & 3 \\
\hline $\mathrm{PD}(\mathrm{X})$ & Pear decline & California & - & NS \\
\hline EPN & Elm yellows & New York & - & NS \\
\hline LY & Coconut lethal yellows & Florida & - & 3 \\
\hline AT & Apple proliferation & Germany & - & 3 \\
\hline WL & Sugarcane white leaf & Thailand & - & 3 \\
\hline BG & Bermudagrass white leaf & Thailand & - & 3 \\
\hline MBS & Maize bushy stunt & Florida & - & 3 \\
\hline \multicolumn{5}{|c|}{ Spiroplasmas } \\
\hline S. citri & & Morocco & - & NS \\
\hline S. kunkelii & & California & - & NS \\
\hline
\end{tabular}

NS, data not shown.

* Faint + with pAYC3, - with pAYC4.

genetic dissimilarity of virescence- and decline-type MLOs (Kirkpatrick et al., 1987, 1988, 1990). In these studies, most of the cloned X-MLO DNA fragments hybridized with other MLOs that cause decline of woody tree species, but did not hybridize with DNA from western AY-MLO strains. Serological relationships that have been identified between MLOs using polyclonal and monoclonal antisera also generally reflect the genetic differences between virescence- and decline-type MLOs described above (Clark et al., 1983, 1989; Sinha \& Benhamou, 1983; Kirkpatrick \& Garrot, 1984; Sinha \& Chiykowski, 1984; Lin \& Chen, 1985; Jiang et al., 1989).

Neither SAY probe hybridized with the two plantpathogenic Spiroplasma species (Table 1, Fig. 3). This result and hybridization results presented elsewhere clearly show that the plant-pathogenic MLOs are genetically distinct from the plant-pathogenic spiroplas- mas (Kirkpatrick et al., 1987; Kuske \& Kirkpatrick, 1990; Lee \& Davis, 1988; Lee et al., 1990).

\section{Hybridization analyses of virescence MLOs}

The SAY chromosomal probes hybridized with DNA from three symptomatically distinct strains of western AY-MLO (SAY, DAY, TLAY), two AY-MLO field isolates from northern California (AY-HR, AY-DAV), two eastern AY-MLO strains (EAY, WAY) and one European AY-MLO strain (AV). However, neither SAY probe hybridized with an AY-MLO strain from Canada (CAY) that produced symptoms in periwinkle which were very similar to those produced by DAY. Unlike the other AY-MLO strains, CAY did not possess extrachromosomal DNA with homology to SAY plasmids (Kuske et al., 1991). In addition, DNA from plants infected with 
the beet-leafhopper-transmitted virescence agent (BLTVA), potato witches' broom MLO (PWB), clover proliferation (CP) and sesame phyllody (SP) did not hybridize with the SAY chromosomal probes. Whether there are genetic similarities between these non-hybridizing virescence MLOs is unknown. However, these hybridization and serological results suggest there are at least two distinct clusters of MLOs that cause virescence and phyllody symptoms in plants.

\section{Restriction fragment length polymorphisms ( $R F L P s)$ of $S A Y$-related MLOs}

RFLP patterns of EcoRI-digested DNAs were used to further study the genetic similarities and differences between the SAY-related virescence MLOs (Fig. 2). Using moderately stringent wash conditions, multiple banding patterns were common in many of the MLO RFLPs, a result that was unexpected considering the general lack of repetitive DNA sequences in most wallless prokaryotes (Razin 1985). Multiple banding patterns were also observed in an eastern AY-MLO strain (Lee \& Davis, 1988). Banding patterns produced by the pAYC3 probe were different from those produced by the pAYC4 probe. Three groups of virescence MLOs were identified that had identical or very similar RFLP patterns: (i) the three strains of western AY-MLO (SAY, DAY and TLAY), (ii) the eastern AY-MLO isolates and virescence agents (EAY, WAY and OAY) and (iii) a European group containing SP, DIV and ST.

RFLP patterns of the three western AY-MLO strains, SAY, DAY and TLAY, were identical when probed with the pAYC3 insert. When probed with the pAYC4 insert, DAY could be distinguished from the other two western AY-MLO strains by the presence of an additional $2.5 \mathrm{~kb}$ band (Fig. $2 b, 3 b$ ). The multiple hybridization pattern of these three strains was repeated at least four times using different DNA preparations, and represents the presence of similar sequences in multiple fragments of the MLO genome, rather than incomplete digestion of the DNA.

The eastern AY-MLO isolate from Wisconsin (WAY) and the Oenothera virescence agent (OAY) had identical RFLP patterns when hybridized with either SAY probe. These RFLP patterns were similar, but not identical, to those of a New Jersey isolate of eastern aster yellows (EAY). The RFLPs of these eastern US virescence MLOs could be readily distinguished from the three western AY-MLO strains. The western AY-MLO strains were originally described as the celery-infecting strains (Severin \& Frazier, 1945), to differentiate them from the non-celery-infecting, eastern AY-MLO strains (Chiykowski, 1973). However, celery-infecting isolates are now present in all geographical regions of North
America, and strain differentiation based on symptoms and plant host range is now impossible. These RFLPs provide genetic markers for differentiating western from eastern AY-MLO strains.

RFLP patterns of Diplotaxis virescence MLO (DIV) from Spain, safflower phyllody MLO (SP) from Israel, and stolbur (ST) from Yugoslavia were identical, indicating that the MLOs causing these three diseases are genetically similar organisms. DIV produces plant symptoms similar to those produced by the AY-MLO strains; however, the symptoms of SP or ST infection do not resemble DIV infection (Kollar \& Seemüller, 1989; E. Seemüller, unpublished data).

DNA hybridization analysis using MLO-specific chromosomal fragments allows related MLOs to be grouped on the basis of the pathogen's genotype, rather than phenotypic characteristics of the MLO-host interaction. DNA hybridization and RFLP analyses can be used to help differentiate the hundreds of plantpathogenic MLO diseases described to date, and provide a basis for rapid identification of unknown MLO isolates. Hybridization analyses are rapid compared to other biological tests and they provide consistent results. When used in conjunction with plant symptoms, host range, insect vector relationships, and antigenic properties, hybridization analysis will facilitate the development of a more precise scheme for classifying plantpathogenic MLOs.

The authors would like to thank T. A. Chen, M. Davis, D. A. Golino, C. Hiruki, A. H. Purcell, B. B. Sears, W. A. Sinclair and R. E. Davis for providing MLO-infected plant material, and N. Harrison for providing DNA extracted from lethal-yellows-infected and healthy Veitchia.

\section{References}

Ausubel, F. M., Brent, R., Kingston, R. E., Moore, D. D., Seidman, J. G., Smith, J. A. \& STRUHL, K. (editors) (1987). Current Protocols in Molecular Biology. New York: Green Publishing Association and Wiley Interscience.

Chiykowski, L. N. (1973). The aster yellows complex in North America. Proceedings North Central Branch, Entomological Society of America 28, 60-66.

Clark, M. G., Barbara, D. J. \& Davies, D. L. (1983). Production and characteristics of antisera to Spiroplasma citri and clover phyllodyassociated antigens derived from plants. Annals of Applied Biology 103. 251-259.

Clark, M. F., Morten, A. \& Buss, S. L. (1989). Preparation of mycoplasma immunogens from plants and a comparison of polyclonal and monoclonal antibodies made against primula yellows MLO-associated antigens. Annals of Applied Biology 114, 111-124.

Davis, M. J., Tsai, J. H., Cox, R. L., MCDaniel, L. L. \& Harrison, N. A. (1988). Cloning of chromosomal and extrachromosomal DNA of the mycoplasma-like organism that causes maize bushy stunt disease. Molecular Plant-Microbe Interactions 1, 295-302.

FreITAG, J. H. (1964). Interaction and mutual suppression among three strains of aster yellows virus. Virology 24, 401-413.

Golino, D. A., Oldfield, G. N. \& GuMPF, D. J. (1987). Transmission characteristics of the beet leafhopper transmitted virescence agent. Phytopathology 77, 954-957. 
JiAng, Y. P. \& Chen, T. A. (1987). Purification of mycoplasmalike organisms from lettuce with aster yellows disease. Phytopathology 77, 949-953.

JiAng, Y. P., Chen, T. A., ChIykowski, L. N. \& SinHA, R. C. (1989). Production of monoclonal antibodies to peach eastern X-disease agent and their use in disease detection. Canadian Journal of Plant Pathology 11, 325-331.

KIRKPATRICK, B. C. (1989). Strategies for characterizing plant pathogenic mycoplasma-like organisms and their effects on plants. In Plant-Microbe Interactions, Molecular and Genetic Perspectives, vol. 3, pp. 241-293. Edited by T. Kosuge \& E. W. Nester. New York: McGraw-Hill.

KiRKPATRICK, B. C. (1991). Mycoplasma-like organisms. Plant and invertebrate pathogens. In The Prokaryotes, vol. 2. Edited by A. Balows, G. H. Trüper, M. Dworkin, W. Harder \& K. H. Schliefer. New York: Springer (in the Press).

KIRKPATRICK, B. C. \& GARROT, D. G. (1984). Detection of western $\mathrm{X}$-disease mycoplasma-like organisms by enzyme-linked immunosorbent assay. Phytopathology 74, 825 (abstract).

Kirkpatrick, B. C., Stenger, D. C., Morris, T. J. \& Purcell, A. H. (1987). Cloning and detection of DNA from a nonculturable plant pathogenic mycoplasma-like organism. Science 238, 197-200.

KirkPatrick, B. C., Fraser, J. D. \& Fisher, G. A. (1988). Genetic and serological relationships between western $\mathrm{X}$-disease mycoplasma-like organism (WX-MLO) and other mollicutes. Phytopatho$\log y$ 78, 1603 (abstract).

Kirkpatrick, B. C., Fisher, G. A., Fraser, J. D. \& Purcell, A. H. (1990). Epidemiological and phylogenetic studies on western $\mathrm{X}$-disease mycoplasma-like organisms. In Recent Advances in Mycoplasmology (Zentralblatt für Bakteriologie, Supplement 20), pp. 287-297. Edited by G. Stanek, G. H. Cassell, J. G. Tully \& R. F. Whitcomb. Stuttgart: Gustav Fischer.

Kollar, A. \& SeEmüller, E. (1989). Base composition of the DNA of mycoplasma-like organisms associated with various plant diseases. Journal of Phytopathology 127, 177-186.

Kollar, A., Seemüller, E., Bonnet, F., Saillard, C. \& Bové, J. M. (1990). Isolation of the DNA of various plant pathogenic mycoplasma-like organisms from infected plants. Phytopathology 80, 233237.

KUSKE, C. R. (1989). Molecular characterization of the western aster yellows mycoplasma-like organisms. $\mathrm{PhD}$ thesis, University of California, Davis.

KusKE, C. R. \& KIRKPATRICK, B. C. (1989). Identification and differentiation of aster yellows MLO strains using aster yellows MLO-specific DNA probes and RFLP analysis. Phytopathology 79, 1209 (abstract).

KUSKE, C. R. \& KIRKPATRICK, B. C. (1990). Isolation and characterization of plasmids from the western aster yellows mycoplasma-like organism. Journal of Bacteriology 172, 1628-1633.
Kuske, C. R., Kirkpatrick, B. C., Davis, J. M. \& Seemüller, E. (1991). DNA hybridization between western aster yellows mycoplasma-like organism plasmids and extrachromosomal DNA from other plant pathogenic mycoplasma-like organisms. Molecular Plant-Microbe Interactions (in the Press).

LEE, I.-M. \& DAVIS, R. E. (1988). Detection and investigation of genetic relatedness among aster yellows and other mycoplasmalike organisms by using cloned DNA and RNA probes. Molecular PlantMicrobe Interactions 1, 303-310.

LeE, I.-M., Davis, R. E. \& DeWITT, N. D. (1990). Nonradioactive screening method for isolation of disease-specific probes to diagnose plant diseases caused by mycoplasma-like organisms. Applied and Environmental Microbiology 56, 1471-1475.

LIN, C.-P. \& ChEN, T. A. (1985). Monoclonal antibodies against the aster yellows agent. Science 227, 1233-1235.

Maniatis, T., FriTsCh, E. F. \& Sambrook, J. (1982). Molecular Cloning, a Laboratory Manual. Cold Spring Harbor, NY: Cold Spring Harbor Laboratory.

McCoy, R. E., Caudwell, A., Chang, C. J., Chen, T. A., Chiykowski, L. N., Cousin, M. T., Dale, De LeeuW, G. T. N., Golino, D. A., Hackett, K. J., KirkPatrick, B. C., Marwitz, R., Petzold, H., Sinha, R. C., Sugiura, M., Whitcomb, R. F., Yang, I. L., ZHU, B. M. \& SeEmülleR, E. (1989). Plant diseases associated with mycoplasma-like organisms. In The Mycoplasmas, vol. 5, pp. 545-560. Edited by R. F. Whitcomb \& J. G. Tully. New York: Academic Press.

Raju, B. C., Nyland, G. \& Purcell, A. H. (1983). Current status of the etiology of pear decline. Phytopathology 73, 350-355.

RazIN, S. (1985). Molecular biology and genetics of Mycoplasmas (Mollicutes). Microbiological Reviews 49, 419-455.

SchafF, D. A., LeE, I.-M. \& Davis, R. E. (1990). Sensitive detection of mycoplasma-like organisms (MLOs) by polymerase chain reactions (PCR). Phytopathology 80, 959 (abstract).

Sears, B. B., Lim, P.-O., Holland, N., Kirkpatrick, B. C. \& KLOMPARENS, K. L. (1989). Isolation and characterization of DNA from a mycoplasma-like organism. Molecular Plant-Microbe Interactions 2, 175-180.

SEVERIN, H. H. P. \& Frazier, N. W. (1945). California aster yellows on vegetable and seed crops. Hilgardia 16, 573-596.

Sinha, R. C. \& Benhamou, N. (1983). Detection of mycoplasma-like organism antigens from aster yellows-diseased plants by two serological procedures. Phytopathology 73, 1199-1202.

SiNHA, R. C. \& CHIYKowSKI, L. N. (1984). Purification and serological detection of mycoplasma-like organisms from plants affected by peach eastern X-disease. Canadian Journal of Plant Pathology 6, 200205.

Yanisch-Perron, C., Vieira, J. \& Messing, J. (1985). Improved M13 phage cloning vectors and host strains: nucleotide sequences of the M13mpl8 and pUC19 vectors. Gene 33, 103-119. 